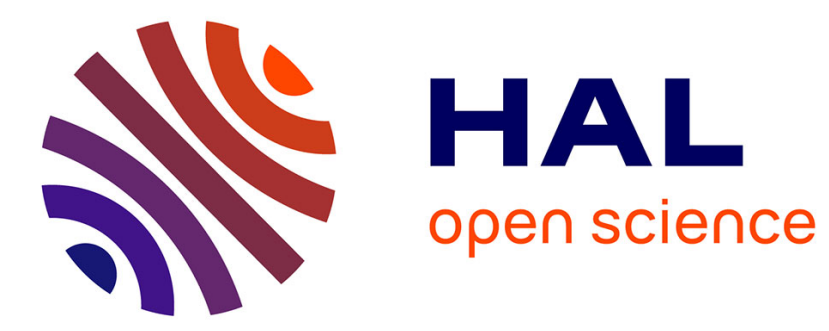

\title{
A new carboxylic chelate ligand and its supramolecular complexes formed with sodium ions and alcohol molecules
}

Jan Marten, Wilhelm Seichter, Edwin Weber

\section{- To cite this version:}

Jan Marten, Wilhelm Seichter, Edwin Weber. A new carboxylic chelate ligand and its supramolecular complexes formed with sodium ions and alcohol molecules. Supramolecular Chemistry, 2010, 22 (03), pp.163-171. 10.1080/10610270902980648 . hal-00566324

\section{HAL Id: hal-00566324 \\ https://hal.science/hal-00566324}

Submitted on 16 Feb 2011

HAL is a multi-disciplinary open access archive for the deposit and dissemination of scientific research documents, whether they are published or not. The documents may come from teaching and research institutions in France or abroad, or from public or private research centers.
L'archive ouverte pluridisciplinaire HAL, est destinée au dépôt et à la diffusion de documents scientifiques de niveau recherche, publiés ou non, émanant des établissements d'enseignement et de recherche français ou étrangers, des laboratoires publics ou privés. 


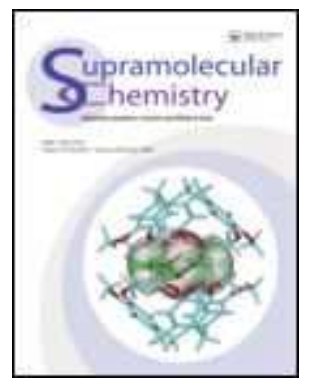

\section{A new carboxylic chelate ligand and its supramolecular complexes formed with sodium ions and alcohol molecules}

\begin{tabular}{|r|l|}
\hline Journal: & Supramolecular Chemistry \\
\hline Manuscript ID: & GSCH-2009-0019.R1 \\
\hline Manuscript Type: & Full Paper \\
\hline Date Submitted by the & 07-Apr-2009 \\
\hline Complete List of Authors: & $\begin{array}{l}\text { Marten, Jan; ChemCycle Bitterfeld GmbH, Forschung und } \\
\text { Entwicklung } \\
\text { Seichter, Wilhelm; TU Bergakademie Freiberg, Organische Chemie } \\
\text { Weber, Edwin; TU Bergakademie Freiberg, Organische Chemie }\end{array}$ \\
\hline Keywords: & $\begin{array}{l}\text { chelate ligand, sodium coordination, alcoholic supramolecular } \\
\text { complexes, X-ray crystal structures, hydrogen bonds }\end{array}$ \\
\hline
\end{tabular}

\section{今scholaronE" \\ Manuscript Central}




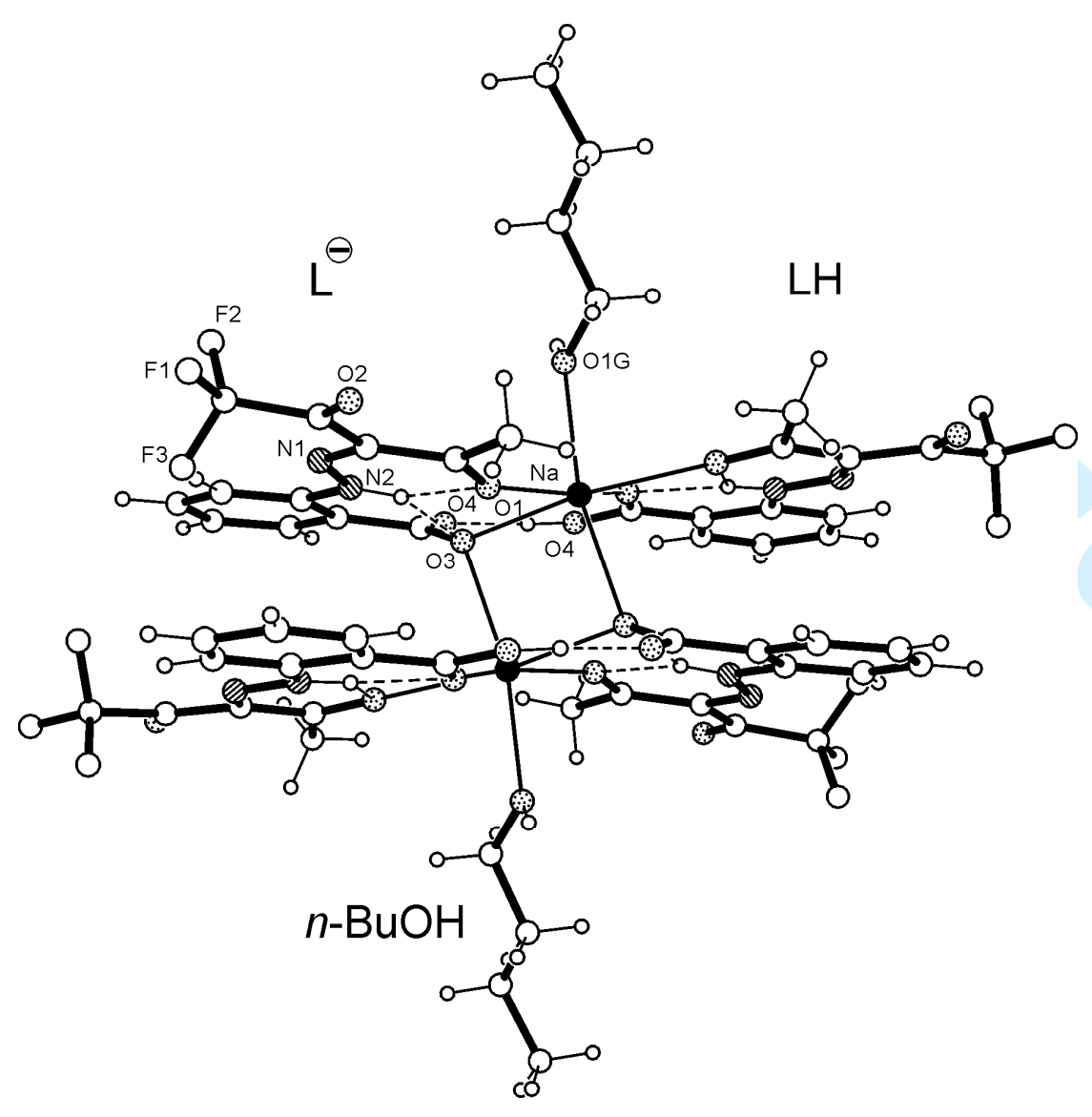

Jan Marten, Wilhelm Seichter and Edwin Weber

A new carboxylic chelate ligand and its supramolecular complexes formed with sodium ions and alcohol molecules 


\title{
A new carboxylic chelate ligand and its supramolecular complexes formed with sodium ions and alcohol molecules
}

\author{
Jan Marten, Wilhelm Seichter and Edwin Weber* \\ Institut für Organische Chemie, Technische Universität Bergakademie Freiberg, \\ Leipziger Straße 29, Freiberg/Sachsen, Germany
}

\footnotetext{
* Corresponding author. E-mail: edwin.weber@ chemie.tu-freiberg.de
} 


\begin{abstract}
The new hydrazone ligand 1, featuring a 2-carboxy group at the aromatic ring and a trifluoromethyl structural modification in the pentane-2,4-dione moiety, has been synthesized via the Japp-Klingemann route. The compound is shown to form binuclear multicomponent chelate complexes ( $\mathbf{2}$ and $\mathbf{3}$ ) composed of two sodium ions, two charge equalizing carboxylates of the hydrazone molecule, two more carboxylic hydrazones and two alcoholic solvent molecules, with the latter being either $\mathrm{EtOH}$ or $n-\mathrm{BuOH}$. X-ray crystal structures of the free hydrazone ligand as well as of the complexes have been studied. They demonstrate for the free ligand a ribbon-type aggregation of carboxylic dimers, while the isomorphous complexes possess a remarkable binuclear structure with the two sodium ions in an distorted octahedral coordination geometry of six oxygen atoms coming, as the equatorial and apical sites, from the hydrazone carbonyl groups and the hydroxyl of the solvent molecules, respectively. Hydrogen bonds owing to the alcohol molecules give rise to stack formation of the supramolecular cluster. Weak intermolecular contacts involving the fluorine atoms are also contributing to the crystalline packing both in the case of the free ligand and the complexes.
\end{abstract}

Keywords: chelate ligand; sodium coordination; alcoholic supramolecular complexes; X-ray crystal structures; hydrogen bonds 


\section{Introduction}

The binding and transport of the sodium and potassium metal ions are of vital importance to life (1). Naturally occurring substances, capable of performing these processes, are given by the well-known ionophores such as valinomycin and nonactin (2). The rapid development of the crown compounds (3), as an exemplary synthetic mimic, has presented us with an immense variety of macrocyclic ligands (4) that form complexes with alkali metal ions of different thermodynamics and kinetics (5), corresponding to their degree of preorganization (6). In this connection, noncyclic analogues of the crown compounds, designated as podands (7), that form complexes with main group I metal ions, have also been prepared in a wide range $(8,9)$. Besides these noncyclic ligands of aprotic nature, the protic complexones are another important class of ligands providing neutral chelate complexes of inner salt type with alkali and alkaline earth metal ions (7). Some of them are traditional tools in analytical chemistry (10). Other have been studied with regard to their biological activity (11-13) or specific coordination geometry $(14,15)$. Recent challenges arise from current topics of supramolecular chemistry (6) involving crystal engineering (16) and molecular recognition behaviour $(17,18)$, aiming at the design of sorptive materials that may be used for compound storage $(19,20)$ or chemical sensing $(21)$. Particular transition metal complexes, known as the MOF type coordination polymers $(22,23)$, are currently a very active field of research in these respects while corresponding complexes formed of main group metal ions, especially alkali and alkaline earth metal ions, are up for development..

In a previous paper (24), we reported on the complexes of 3-(arylhydrazono)pentane-2,4diones with the transition metal ions copper(II) and nickel(II). Moreover, we found that fluorine substitution in the pentane-2,4-dione moiety of the hydrazone gave rise to a particular packing mode in the crystal structure (25), which could also pay here. We now describe for the first time complexes of a respective hydrazone 1 with sodium ions, containing additional alcohol molecules in the coordination sphere, to yield an interesting new type of supramolecular aggregate structure. In terms of facts, the present complexes are composed of molecules of the hydrazone 1, the carboxylate of $\mathbf{1}$, sodium ions and ethanol (2) or $n$-butanol solvent molecules (3) in a stoichiometric ratio 2:2:2:2, respectively, considering the formed cluster unit (Scheme 1). Synthesis of the compounds (1-3) is presented and their X-ray crystal structures are discussed. 


\section{Results and discussion}

\section{Synthesis of compounds}

The free arylhydrazone ligand 1 was synthesized via Japp-Klingemann reaction (26) between the diazonium salt of 2-aminobenzoic acid and 1,1,1-trifluoropentane-2,4-dione in a methanolic solution containing sodium acetate (27). The diazonium salt was prepared by usual diazotation of 2aminobenzoic acid (28). The complexes $\mathbf{2}$ and $\mathbf{3}$ were obtained by recrystallization of crude $\mathbf{1}$ from ethanol and $n$-butanol, respectively, in the presence of sodium ions, coming from the reaction components.

\section{Structural Study}

The crystal data, experimental parameters and selected details of the refinement calculations are summarized in Table 1. Information regarding conformational features and possible non-covalent interactions in the crystal structures are presented in Tables 2-4. Molecular structures are depicted in Figs. 1, 3 and 4, while packing illustrations are presented in Figs. 2 and 5.

\section{Crystal structures of the free ligand (1)}

The hydrazone 1 crystallizes from toluene as yellow rods of the triclinic space group $P-1$. The molecular structure including the atom numbering scheme is presented in Fig.1. Being in conformity with the crystal structure analyses of related compounds $(24,25,29)$, the molecular structure of 1 shows the presence of an intramolecular six-membered hydrogen bonded ring formed between the N-bound hydrogen $\mathrm{H}(2)$ and one of the oxygens of the pentane-2,4-dione fragment $\left[\mathrm{N}(2)-\mathrm{H}(2) \cdots \mathrm{O}(1) 1.90 \AA, 131.2^{\circ}\right.$ ]. In addition, this hydrogen atom is bonded to $\mathrm{O}(3)$ of the carboxy substituent $\left[\mathrm{N}(2)-\mathrm{H}(2) \cdots \mathrm{O}(3) 2.00 \AA, 126.5^{\circ}\right.$ ], giving rise to a bifurcated bonding situation for $\mathrm{H}(2)$. The fact that the oxygen of the $\mathrm{CH}_{3} \mathrm{CO}$ moiety is used for strong intramolecular hydrogen bonding indicates the higher acceptor ability compared to the $\mathrm{CF}_{3} \mathrm{CO}$ unit. The oxygen of this latter fragment is involved only in weak intermolecular hydrogen bonding. Two of the fluorine atoms of each molecule take part in molecular cross-linking by forming weak $\mathrm{C}-\mathrm{H} \cdots \mathrm{F}$ and $\mathrm{C}-\mathrm{F}$...F contacts (30,

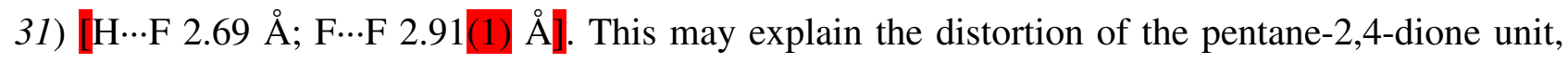


which is reflected by the torsion angles that deviate significantly from ideal values of 0 and $180^{\circ}$ (Table 2).

As diplayed in Fig. 2, in the crystal structure of 1, molecules interact among each other by hydrogen bonding of their carboxylic acid groups $\left[\mathrm{O}(4)-\mathrm{H}(4) \cdots \mathrm{O}(3) 1.81 \AA\right.$, $\left.174.5^{\circ}\right]$, thus forming conventional centro-symmetric dimers. They are further linked by bifurcated $\mathrm{C}-\mathrm{H} \cdots \mathrm{O}$ hydrogen bonds (32) $\left[\mathrm{C}(8)-\mathrm{H}(8) \cdots \mathrm{O}(2) 2.58,121.7^{\circ}, \mathrm{C}(9)-\mathrm{H}(9) \cdots \mathrm{O}(2) 2.53,123.2^{\circ}\right]$, resulting in infinite supramolecular ribbons. Generally, the packing structure consists of two-dimensional molecular sheets being linked among each other through C-H...F contacts.

\section{Crystal structures of the sodium complexes $\mathbf{2}$ and $\mathbf{3}$}

Crystallization of the aryl hydrazone 1 from ethanol or $n$-butanol in the presence of sodium ions from the crude product yields complexes of the composition $\left[\mathrm{Na}_{2} \mathrm{~L}_{2}(\mathrm{LH})_{2}\right] \cdot 2 \mathrm{ROH}$ as yellow rods. For each of the two complexes, the asymmetric unit of the cell contains one half of the molecule, i.e. the complexes exhibit inversion symmetry. The structure of the $\mathrm{Na}^{+}(\mathrm{LH}) \mathrm{L}^{-}$unit and the molecular structures of the complexes with the labelling of relevant atoms are depicted in Figs. 3 and 4, respectively. The space group symmetries $\left(P 2_{1} / n\right)$ as well as the crystallographic parameters (Table 1) indicate that the structures of $\mathbf{2}$ and $\mathbf{3}$ are isomorphous. Hence, a detailed structural description can be confined to the crystal structure of $\mathbf{2}$, being transferable to 3 .

In the binuclear complex of $\mathbf{2}$, which is constructed of two anionic $\left(\mathrm{L}^{-}\right)$and two uncharged ligands (LH), the sodium ions adopt a distorted octahedral coordination environment [Fig. 4(a)]. The equatorial positions within the coordination polyhedron are occupied by the oxygens of two ligands with $\mathrm{Na}-\mathrm{O}$ distances ranging between 2.284(2) and 2.382(2) $\AA$. The axial positions are occupied by the oxygen of the disordered ethanol molecule (SOF: 0.67, 0.33) and the carboxylate oxygen which is simultaneously bonded to both sodium ions. The corresponding Na-O distances are $2.463(2)[2.260(2)]$ and $2.421(2) \AA$, respectively; the $\mathrm{Na} \cdots \mathrm{Na}$ distance is $3.402(2) \AA$. A conformational analysis of the complex ligands $\mathrm{LH}$ and $\mathrm{L}^{-}$reveals less differences regarding their bond lengths, but show different degrees of distortion of their pentane-2,4-dione fragments (Table 2), which can be ascribed to an asymmetric coordinating behaviour of the fluorine atoms of the respective $\mathrm{CF}_{3} \mathrm{CO}$ moiety. Only one fluorine atom of the anionic ligand is involved in intermolecular association via $\mathrm{C}-\mathrm{H} \cdots \mathrm{F}$ hydrogen bonding $(30,31)$, whereas in the protonated ligand all fluorine atoms take part in this kind of interaction. Another striking difference between the ligands is the inclination of the carboxylate group with respect to the aromatic ring to which it is 


\section{Comparative reflection and conclusions}

The new carboxylic hydrazone ligand $\mathbf{1}$ and its uncharged supramolecular complexes, containing beside sodium ions EtOH (2) or $n$-BuOH (3) solvent molecules, were studied by X-ray crystal structure technique, giving rise to the following statement.

The molecular geometry of $\mathbf{1}$ is virtually the same as found for other previously studied fluorine-free and fluorine-containing examples of this compound class, showing the intramolecular six-membered hydrogen bonded ring and the overall planar geometry due to extensive conjugation of the $\pi$-electron system $(24,25,29)$. Also, the fact that the acetyl unlike the trifluoroacetyl oxygen of the pentane-2,4-dione moiety is forming the intramolecular hydrogen bond is revealed in the structure of compound 1. Hence, a constitutional modification by an ortho-substituted carboxylic group does not markedly affect the conformational solid state structure inherent of the hydrazone framework but actually helps stabilizing the planar geometry of the molecule by additional 
intramolecular hydrogen bonding. A rather comparable situation with involvement of an additional oxygen atom in intramolecular hydrogen bonding was found for a related hydrazone featuring two ortho positioned nitro substituents (29). By way of contrast, the carboxylic function of $\mathbf{1}$ has a strong bearing on the packing structure in that hydrogen bonded dimers are formed, leading to supramolecular ribbons which determine the lattice structure.

An almost planar geometry of the hydrazone molecule(s) stabilized by an analogous network of intramolecular hydrogen bonds, incorporating the carboxyl and carboxylate oxygens, respectively, is also shown in the isomorphous structures of the sodium complexes $\mathbf{2}$ and $\mathbf{3}$. In other words, the conformational structure of the hydrazone molecules is only little affected by the formation of the carboxylate group and binding to the sodium ion, unlike the packing in the crystal, leading to the specific formation of a binuclear alcohol containing cluster around the sodium ions. That is, the carboxylic dimers in $\mathbf{1}$ are broken at a single site of the hydrogen bonded ring by the deprotonation followed by an insert of the sodium ion. The binuclear complexes associate in a stack stabilized via hydrogen bonding through the alcohol molecules, whereas the contact between neighbouring stacks is only of weak $\mathrm{C}-\mathrm{H} \cdots \mathrm{F}$ type of interaction. Therefore, the overall supramolecular packing motif is ribbon-type for $\mathbf{1}$ and stack-like for $\mathbf{2}$ and $\mathbf{3}$, in each case being involved in a weak interconnection through the intermediary of fluorine atoms.

In summary, we have shown that this particular compound class of arylhydrazones not only yields complexes with soft transition metal ions such as $\mathrm{Cu}^{2+}$ and $\mathrm{Ni}^{2+}$, but also is capable of forming chelate type complexes with the hard alkali metal ion $\mathrm{Na}^{+}$. This gives rise to an interesting supramolecular aggregate, comprising in addition to the two metal ions and the two charge equalizing carboxylates of the hydrazone two more carboxylic hydrazones and two alcoholic solvent molecules for the construction of the supramolecular cluster. A challenging idea for a future structural design is to exchange the simple alcohol molecules for multivalent alcohols or more specific tectones (33) featuring other coordinative functions. Investigations into this direction are aiming work of our group.

\section{Experimental}

\section{General}

Elemental analysis: Heraeus CHN rapid analyzer; MS(EI): Finnigan MAT 8200; FT-IR: KBr disc, Nicolet 510; NMR (internal standard TMS): Bruker Avance DPX 400. Starting compounds (2aminobenzoic acid and 1,1,1-trifluoropentane-2,4-dione) were purchased from Aldrich. 


\section{Synthesis}

\section{3-[(2-Carboxyphenyl)hydrazono]-1,1,1-trifluoropentane-2,4-dione, LH (1)}

A solution of the diazonium salt was prepared under cooling $\left(0-5{ }^{\circ} \mathrm{C}\right)$ from 2-aminobenzoic acid (2.6 g, $19 \mathrm{mmol})$ in hydrochloric acid $(3 \mathrm{~N}, 40 \mathrm{ml})$ and a conc. aqueous solution of sodium nitrite (1.3 g, $19 \mathrm{mmol})$, according to the standard procedure (27). The cold solution of the diazonium salt was added under cooling $\left(0{ }^{\circ} \mathrm{C}\right)$ and stirring to a mixture being composed of 1,1,1-trifluoropentane2,4-dione (2.28 ml, $2.93 \mathrm{~g}, 19 \mathrm{mmol}), \mathrm{NaOH}$ (1.0 g, $25 \mathrm{mmol})$, sodium acetate $(7.5 \mathrm{~g}, 92 \mathrm{mmol})$, methanol $(160 \mathrm{ml})$ and water $(160 \mathrm{ml})$. The mixture was allowed to warm to room temperature and stirred for $1 \mathrm{~h}$. The precipitate which had formed was collected, washed with water, dried and recrystallized from toluene to afford $5.3 \mathrm{~g}(92 \%)$ yellow crystals; mp $249-251{ }^{\circ} \mathrm{C}$ (dec.). IR ( $\mathrm{KBr}$, $\mathrm{cm}^{-1}$ ): 3336 (s, N-H), 1677 (s, C=O), 1639 (s, C=O), 1591 (s, C=N), 1380-1356 (s, CO-CH ( $_{3}, 758$ (s, Ar-H); ${ }^{1} \mathrm{H}-\mathrm{NMR}\left(400 \mathrm{MHz}, \mathrm{CDCl}_{3}\right) \delta 2.49\left(\mathrm{~s}, 3 \mathrm{H}, \mathrm{CH}_{3}\right), 7.32\left(\mathrm{t},{ }^{3} J_{\mathrm{HH}}=8.0 \mathrm{~Hz}, 1 \mathrm{H}, p-\mathrm{Ar}-H\right), 7.67$ $\left(\mathrm{t},{ }^{3} J_{\mathrm{HH}}=8.0 \mathrm{~Hz}, 1 \mathrm{H}, m-\mathrm{Ar}-H\right), 7.83\left(\mathrm{~d},{ }^{3} J_{\mathrm{HH}}=8.0 \mathrm{~Hz}, 1 \mathrm{H}, o-\mathrm{Ar}-\mathrm{H}\right) 8.03\left(\mathrm{~d},{ }^{3} J_{\mathrm{HH}}=8.0 \mathrm{~Hz}, 1 \mathrm{H}\right.$, $m$-Ar- $H$ ), $11.94(\mathrm{~s}, 1 \mathrm{H}, \mathrm{COOH}), 16.32(\mathrm{~s}, 1 \mathrm{H}, \mathrm{NH}) ;{ }^{13} \mathrm{C}-\mathrm{NMR}\left(100.6 \mathrm{MHz}, \mathrm{CDCl}_{3}\right) \delta 30.84\left(\mathrm{CH}_{3}\right)$, $105.30\left(C \mathrm{~F}_{3}\right), 115.04(o-\mathrm{Ar}-C), 121.01(C-\mathrm{COOH}), 125.74(p-\mathrm{Ar}-C), 129.59(C=\mathrm{N}), 131.53(m-\mathrm{Ar}-$ $C), 133.49(m-\mathrm{Ar}-C), 145.19(C-\mathrm{N}), 167.84(\mathrm{COOH}), 176.03\left(\mathrm{CF}_{3}-C=\mathrm{O}\right), 193.45(C=\mathrm{O})$; MS (EI): $m / z$ calcd for $\mathrm{C}_{12} \mathrm{H}_{9} \mathrm{~F}_{3} \mathrm{~N}_{2} \mathrm{O}_{4}: 302.05$. Found: 302 ([ $\left.\mathrm{M}^{+}\right], 100 \%$ ). Anal. Calcd for $\mathrm{C}_{12} \mathrm{H}_{9} \mathrm{~F}_{3} \mathrm{~N}_{2} \mathrm{O}_{4}: \mathrm{C}$, 56.26; H, 5.04; N, 8.75. Found: C, 56.38; H, 4.96; N, 8.75.

\section{Complex $\left[\mathrm{Na}_{2} \mathrm{~L}_{2}(\mathrm{LH})_{2}\right] \cdot 2 \mathrm{EtOH}(2)$}

The crude product 1 of the above synthetic procedure was recrystallized from ethanol instead of toluene to yield compound $\mathbf{2}$ as yellow crystals that become opaque on storage out of the mother liquor and rapidly decompose on heating to $86-88^{\circ} \mathrm{C}$ with release of the solvent.

\section{Complex $\left[\mathrm{Na}_{2} \mathrm{~L}_{2}(\mathrm{LH})_{2}\right] \cdot 2 \mathrm{n}-\mathrm{BuOH}(\mathbf{3})$}

The crude product $\mathbf{1}$, as provided from synthesis, was recrystallized from $n$-butanol to yield on storage at $0-5{ }^{\circ} \mathrm{C}$ during a period of 2 weeks compound $\mathbf{3}$ as yellow crystals that are rather unstable out of the mother liquor and rapidly decompose at $125-127^{\circ} \mathrm{C}$ with release of the solvent. 


\section{X-ray crystallography}

Single crystals of the compounds 1-3, suitable for X-ray diffraction study, were obtained on recrystallization from solvents as given with the synthetic procedures. The intensity data were collected on a Kappa APEX II diffractometer (Bruker-AXS) with graphit monochromated $\mathrm{CuK}_{\alpha^{-}}$ radiation $(\lambda=0.71073 \AA)$ using $\omega$ - and $\varphi$-scans. Reflections were corrected for background, Lorentz and polarization effects. Preliminary structure models were derived by application of direct methods (34) and were refined by full-matrix least squares calculation based on $\mathrm{F}^{2}$ for all reflections (35). For the metal complexes an empirical absorption correction based on multi-scans was applied by using the SADABS program (36). All non-hydrogen atoms were refined anisotropically. With the exception of the amino hydrogen atom $\mathrm{H}(2)$ in structures $\mathbf{1}-\mathbf{3}$ and the hydroxy hydrogen atom of the alcoholic component in $\mathbf{2}$, all hydrogen atoms were included in the models in calculated positions and were refined as constrained to bonding atoms. The crystal data and experimental parameters are summarized in Table 1. Crystallographic data for the structures in this paper have been deposited with the Cambridge Crystallographic Data Centre as supplementary publication numbers CCDC-720739 (1), CCDC-720740 (2), and CCDC-720738 (3). Copies of the data can be obtained free of charge on application to the Director, CCDC, 12 Union Road, Cambridge CB2 1EZ, UK (Fax: +44-1223-336033, E-mail: deposit@ccdc.cam.ac.uk).

\section{Acknowledgement}

We greatfully acknowledge financial support by the German Federal Ministry of Science and Technology (BMBF) under grant No. 02110120 'Biomon'. 


\section{References}

(1) Skou, J. C. Angew. Chem. 1998, 110, 2452; Angew. Chem. Int. Ed. 1998, 37, 2321.

(2) Ferdani, R.; Gokel, G. W. In Encyclopedia of Supramolecular Chemistry; J. L. Atwood, J. W. Steed, Eds.; CRC Press: Boca Raton, 2004; pp. 760.

(3) Pedersen, C. J. J. Am. Chem. Soc. 1967, 89, 7017.

(4) Atwood, J. L.; Davies, J. E.; MacNicol, D. D.; Vögtle, F.; Eds.; Comprehensive Supramolecular Chemistry; Elsevier: Oxford, 1996; vol. 1.

(5) Inoue, Y.; Gokel, G. W.; Eds.; Cation Binding by Macrocycles; Dekker: New York, 1990.

(6) Steed, J. W.; Turner, D. R., Wallace, K. J. Core Concepts in Supramolecular Chemistry and Nanochemistry; Wiley: Chichester, 2007.

(7) Vögtle, F.; Weber, E. Angew. Chem. 1979, 91, 813; Angew. Chem. Int. Ed. 1997, 18, 753.

(8) Gokel, G. W.; Murillo, O. In Comprehensive Supramolecular Chemistry; J. L. Atwood, J. E. D. Davies, D. D. MacNicol, F. Vögtle, Eds.; Elsevier: Oxford, 1996; vol. 1, pp. 1.

(9) Weber, E. In Encyclopedia of Supramolecular Chemistry, J. L. Atwood, J. W. Steed, Eds.; CRC Press: Boca Raton, 2004; pp. 1106.

(10) Přibil, F. Applied Complexometry; Pergamon: Oxford, 1983.

(11) Kumberger, O; Riede, J.; Schmidbaur, H. Chem. Ber. 1992, 125, 1829.

(12) Browing, K.; Abboud, K. A.; Palenik, G. J. J. Chem. Crystallogr. 1995, 25, 851.

(13) Sagatys, D. S.; Dahlgren, C.; Smith, G.; Bott, R. C.; White, J. M. J. Chem. Soc., Dalton Trans. 2000, 3401.

(14) Kläui, W.; Müller, A.; Eberspach, W.; Boese, R.; Goldberg, I. J. Am. Chem. Soc. 1987, 109, 164.

(15) Doble, D. M. J.; Blake, A. J.; Li, W.-S.; Schröder, M. J. Chem. Soc., Dalton Trans. 2001, 3137.

(16) Tieking, E. R. T.; Vittal, J.; Eds.; Frontiers in Crystal Engineering; Wiley: Hoboken, 2006.

(17) Weber, E. In Kirk Othmer Encyclopedia of Chemical Technology; $4^{\text {th }}$ ed., Suppl.; J. I. Kroschwitz, Ed; Wiley: New York, 1998; pp. 352.

(18) Schneider, H.-J.; Yatsimirsky, A. Principles and Methods in Supramolecular Chemistry, Wiley: Chichester, 2000.

(19) MacNicol, D. D.; Rowan, S. J. In Comprehensive Supramolecular Chemistry; J. L. Atwood, J. E. D. Davies, D. D. MacNicol, F. Vögtle, Eds.; Elsevier: Oxford, 1996; vol. 10, pp. 417.

(20) Hertzsch, T.; Hulliger, J.; Weber, E.; Sozzani, P. In Encyclopedia of Supramolecular Chemistry; J. L. Atwood, J. W. Steed, Eds.; CRC Press: Boca Raton, 2004; pp. 996.

(21) Janata, J. Chem. Rev. 2008, 108, 327. 
(22) Férey, G. Chem. Soc. Rev. 2008, 191 (2008).

(23) Wright, P. A. Microporous Framework Solids; Royal Society of Chemistry: Cambridge, UK, 2008 .

(24) Marten, J.; Seichter, W.; Weber, E. Z. Anorg. Allg. Chem. 2005, 631, 869.

(25) Marten, J.; Seichter, W.; Weber, E.; Böhme, U. CrystEngComm 2008, 10, 541.

(26) Phillips, R. R. Org. React. 1959, 10, 143.

(27) Nouhebel, D. C. Tetrahedron 1979, 35, 2013.

28) Pütter, R. In Methoden Org. Chem. (Houben-Weyl) 1965; vol. 10/3, pp. 1.

(29) Marten, J.; Seichter, W.; Weber, E.; Böhme, U. J. Phys. Org. Chem. 2007, 20, 716.

(30) Reichenbächer, K.; Süss, H. I.; Hulliger, J. Chem. Soc. Rev. 2005, 34, 22.

(31) Schwarzer, A.; Weber, E. Cryst. Growth Des. 2008, 8, 2862.

(32) Desiraju, G. R.; Steiner, T. The Weak Hydrogen Bond in Chemistry and Structural Biology; Oxford University Press: Oxford, 1999.

(33) Sauriat-Dorizon, H. ; Maris, T.; Wuest, J. D. J. Org. Chem. 2003, 68, 240.

(34) Sheldrick, G. M. SHELXS-97: Program for Crystal Structure Solution; University of Göttingen: Germany, 1997.

(35) Sheldrick, G. M. SHELXL-97: Program for Crystal Structure Refinement; University of Göttingen: Germany, 1997.

(36) G. M. Sheldrick, SADABS; University of Göttingen: Germany, 2004. 
Table 1 Crystal data, experimental parameters and selected details of the refinement calculations of compounds 1-3 (Esd's are in parentheses).

\begin{tabular}{|c|c|c|c|}
\hline Compound & 1 & 2 & 3 \\
\hline Formula unit & $\mathrm{C}_{12} \mathrm{H}_{9} \mathrm{~F}_{3} \mathrm{~N}_{2} \mathrm{O}_{4}$ & $\mathrm{C}_{52} \mathrm{H}_{44} \mathrm{~F}_{12} \mathrm{~N}_{8} \mathrm{Na}_{2} \mathrm{O}_{18}$ & $\mathrm{C}_{56} \mathrm{H}_{54} \mathrm{~F}_{12} \mathrm{~N}_{8} \mathrm{Na}_{2} \mathrm{O}_{18}$ \\
\hline Formula weight & 302.21 & 1342.93 & 1401.06 \\
\hline Crystal system & triclinic & monoclinic & monoclinic \\
\hline Space group & $P-1$ & $P 2_{1} / n$ & $P 2_{1} / n$ \\
\hline \multicolumn{4}{|l|}{ Unit cell dimensions } \\
\hline$a, \AA$ & $5.0637(2)$ & $13.3812(9)$ & $13.350(3)$ \\
\hline$b, \AA$ & $8.5278(4)$ & $8.0093(6)$ & $7.9930(2)$ \\
\hline$c, \AA$ & $14.596(1)$ & $27.829(2)$ & $28.931(6)$ \\
\hline$\alpha, \operatorname{deg}$ & $95.317(3)$ & 90 & 90 \\
\hline$\beta, \operatorname{deg}$ & $90.422(2)$ & $97.126(3)$ & $93.25(3)$ \\
\hline$\gamma, \operatorname{deg}$ & $106.144(2)$ & 90 & 90 \\
\hline$V, \AA^{3}$ & $602.45(5)$ & $2959.5(4)$ & $3082.2(12)$ \\
\hline$Z$ & 2 & 2 & 4 \\
\hline$D_{\mathrm{c}}, \mathrm{m}^{-3}$ & 1.666 & 1.507 & 1.510 \\
\hline \multicolumn{4}{|l|}{ Data collection } \\
\hline Temperature, $K$ & $93(2)$ & $153(2)$ & $93(2)$ \\
\hline $\begin{array}{l}\text { No. of collected reflections } \\
\text { within the } \theta \text {-limit, deg }\end{array}$ & 17252 & 30380 & 30443 \\
\hline No. of unique reflections & 3865 & 6522 & 6553 \\
\hline$R_{\text {int }}$ & 0.0379 & 0.0669 & 0.0671 \\
\hline \multicolumn{4}{|l|}{$\begin{array}{l}\text { Refinement calculations } \\
\text { full-matrix least-squares based } \\
\text { on all } F^{2} \text { values }\end{array}$} \\
\hline No. of refined parameters & 196 & 426 & 449 \\
\hline No. of values used $[I>2 \sigma(I)]$ & 2591 & 4243 & 3915 \\
\hline$R\left(=\Sigma|\Delta F| / \Sigma\left|F_{o}\right|\right)$ & 0.0432 & 0.0584 & 0.0494 \\
\hline$w R$ on $F^{2}$ & 0.1334 & 0.1933 & 0.1745 \\
\hline
\end{tabular}


Table 2 Selected structural parameters (distances $/ \AA$, angles $/{ }^{\circ}$ ) involving the ligand molecules in compounds 1-3.

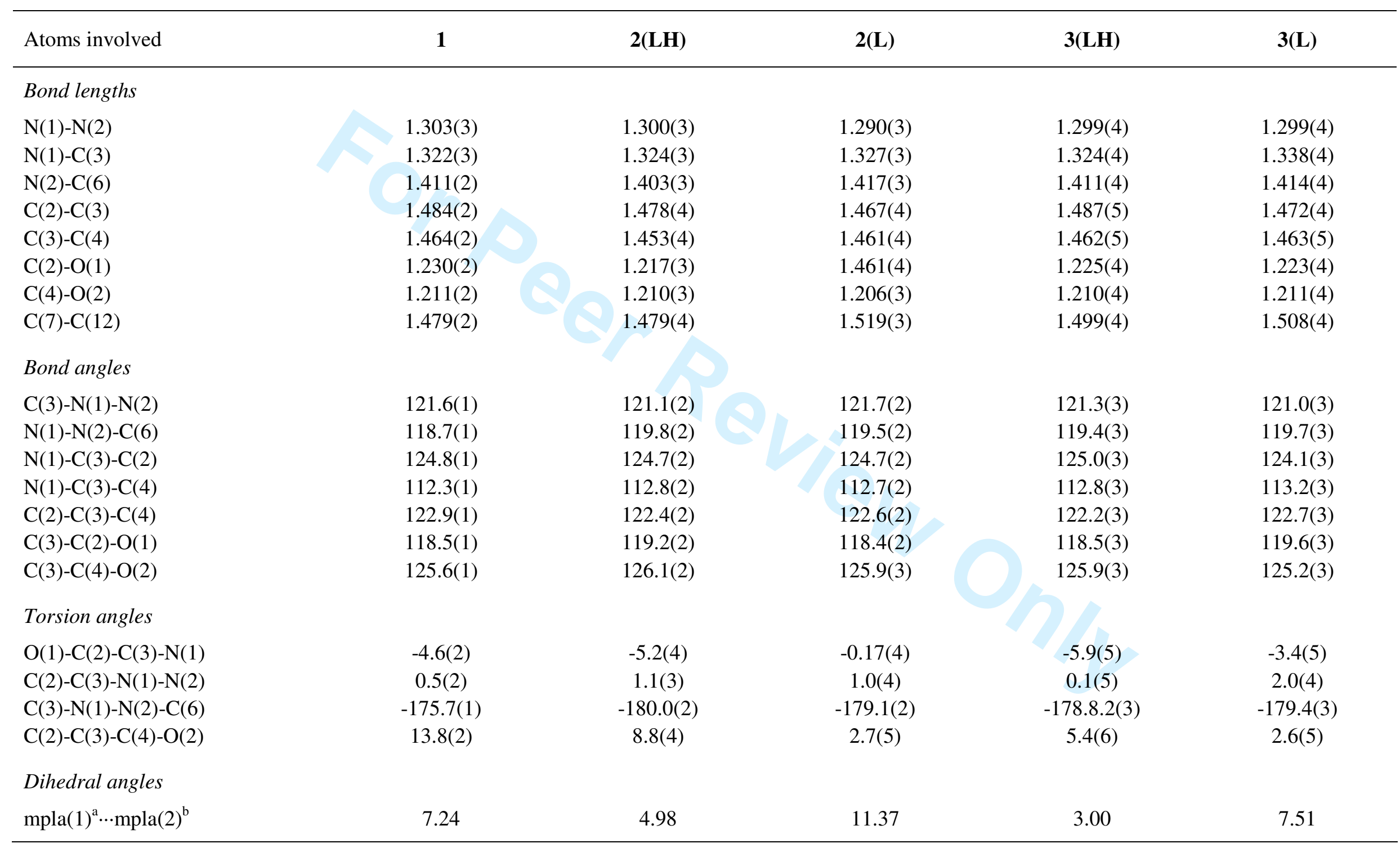

${ }^{\mathrm{a}}$ mpla(1): mean plane through the atoms $\mathrm{C}(6)-\mathrm{C}(7)-\mathrm{C}(8)-\mathrm{C}(9)-\mathrm{C}(10) ;{ }^{\mathrm{b}}$ mpla(2): mean plane through the atoms $\mathrm{H}(2)-\mathrm{N}(2)-\mathrm{N}(1)-\mathrm{C}(3)-\mathrm{C}(2)-\mathrm{O}(1)$. 
Table 3 Bond lengths $(\AA)$ and angles $\left(^{\circ}\right)$ involving $\mathrm{Na}^{+}$in the complexes 2 and $\mathbf{3}$.

\begin{tabular}{lcc}
\hline & $\mathbf{2}$ & $\mathbf{3}$ \\
\hline Bond lengths & & \\
$\mathrm{Na}(1)-\mathrm{Na}\left(1^{\prime}\right)$ & $3.402(2)$ & $3.346(2)$ \\
$\mathrm{Na}(1)-\mathrm{O}(1)$ & $2.341(2)$ & $2.344(2)$ \\
$\mathrm{Na}(1)-\mathrm{O}(1 \mathrm{~A})$ & $2.382(2)$ & $2.423(2)$ \\
$\mathrm{Na}(1)-\mathrm{O}(3)$ & $2.421(2)$ & $2.372(2)$ \\
$\mathrm{Na}(1)-\mathrm{O}\left(3^{\prime}\right)$ & $2.368(2)$ & $2.393(2)$ \\
$\mathrm{Na}(1)-\mathrm{O}(3 \mathrm{~A})$ & $2.284(2)$ & $2.284(2)$ \\
$\mathrm{Na}(1)-\mathrm{O}(1 \mathrm{GA})$ & $2.463(2)$ & $2.291(2)$ \\
$\mathrm{Na}(1)-\mathrm{O}(1 \mathrm{G})$ & $2.260(9)$ & \\
& & \\
Bond angles & & \\
$\mathrm{O}(1 \mathrm{GA})-\mathrm{Na}(1)-\mathrm{O}\left(3^{\prime}\right)$ & $170.7(5)$ & $166.3(1)$ \\
$\mathrm{O}(1)-\mathrm{C}(2)-\mathrm{O}(3 \mathrm{~A})$ & $163.6(1)$ & $161.0(1)$ \\
$\mathrm{O}(3)-\mathrm{C}(4)-\mathrm{O}(1 \mathrm{~A})$ & $162.1(1)$ & $163.3(1)$ \\
\hline
\end{tabular}


Table 4 Structural parameters (distances $/ \AA$, angles $/^{\circ}$ ) of the noncovalent interactions in compound 1-3.

\begin{tabular}{|c|c|c|c|c|c|}
\hline \multirow{2}{*}{$\begin{array}{l}\text { Atoms involved } \\
\text { D-H } \cdots A\end{array}$} & \multirow{2}{*}{ Symmetry } & \multicolumn{3}{|c|}{ Distances } & \multirow{2}{*}{$\begin{array}{c}\text { Angle } \\
\text { D-H } \cdots A\end{array}$} \\
\hline & & D-H & $\mathrm{D} \cdots \mathrm{A}$ & $\mathrm{H} \cdots \mathrm{A}$ & \\
\hline \multicolumn{6}{|l|}{ (1) } \\
\hline $\mathrm{N}(2)-\mathrm{H}(2) \cdots \mathrm{O}(1)$ & $x, y, z$ & 0.92 & $2.598(2)$ & 1.90 & 131.2 \\
\hline $\mathrm{N}(2)-\mathrm{H}(2) \cdots \mathrm{O}(3)$ & $x, y, z$ & 0.92 & $2.655(2)$ & 2.00 & 126.5 \\
\hline $\mathrm{C}(8)-\mathrm{H}(8) \cdots \mathrm{O}(2)$ & $-2+x-1+y, z$ & 0.95 & $3.183(2)$ & 2.58 & 121.7 \\
\hline $\mathrm{C}(9)-\mathrm{H}(9) \cdots \mathrm{O}(2)$ & $-2+x,-1+y, z$ & 0.95 & $3.153(3)$ & 2.53 & 123.2 \\
\hline $\mathrm{O}(4)-\mathrm{H}(4) \cdots \mathrm{O}(3)$ & $-1-x, 1-y, 1-z$ & 0.84 & $2.645(2)$ & 1.81 & 174.5 \\
\hline $\mathrm{C}(9)-\mathrm{H}(9) \cdots \mathrm{F}(2)$ & $-1+x, 1-y, z$ & 0.95 & $3.381(3)$ & 2.69 & 130.3 \\
\hline $\mathrm{C}(10)-\mathrm{H}(10) \cdots \mathrm{F}(3)$ & $1-x, 1-y,-z$ & 0.95 & $3.373(3)$ & 2.70 & 128.7 \\
\hline \multirow[t]{2}{*}{$\mathrm{C}(5)-\mathrm{F}(1) \cdots \mathrm{F}(1)$} & $1-x, 1-y,-z$ & $(\mathrm{C}-\mathrm{F})$ & $(\mathrm{C} \cdots \mathrm{F})$ & $(\mathrm{F} \cdots \mathrm{F})$ & $(\mathrm{C}-\mathrm{F} \cdots \mathrm{F})$ \\
\hline & & 1.33 & $3.379(3)$ & 2.91 & 98.9 \\
\hline \multicolumn{6}{|l|}{ (2) } \\
\hline $\mathrm{N}(2)-\mathrm{H}(2) \cdots \mathrm{O}(1)$ & $x, y, z$ & 0.89 & $2.591(3)$ & 1.94 & 128.8 \\
\hline $\mathrm{N}(2)-\mathrm{H}(2) \cdots \mathrm{O}(3)$ & $x, y, z$ & 0.89 & $2.616(3)$ & 1.92 & 134.0 \\
\hline $\mathrm{C}(9 \mathrm{~A})-\mathrm{H}(9 \mathrm{~A}) \cdots \mathrm{O}(2)$ & $-0.5+x, 1.5+y,-0.5+z$ & 0.95 & $3.580(3)$ & 2.64 & 170.6 \\
\hline $\mathrm{C}(8)-\mathrm{H}(8) \cdots \mathrm{O}(4)$ & $x, y, z$ & 0.89 & $2.703(3)$ & 2.37 & 100.4 \\
\hline $\mathrm{N}(2 \mathrm{~A})-\mathrm{H}(2 \mathrm{~A}) \cdots \mathrm{O}(1 \mathrm{~A})$ & $x, y, z$ & 0.89 & $2.588(3)$ & 1.90 & 133.0 \\
\hline $\mathrm{N}(2 \mathrm{~A})-\mathrm{H}(2 \mathrm{~A}) \cdots \mathrm{O}(3 \mathrm{~A})$ & $x, y, z$ & 0.89 & $2.644(3)$ & 2.00 & 127.8 \\
\hline $\mathrm{O}(1 \mathrm{G})-\mathrm{H}(1 \mathrm{G}) \cdots \mathrm{O}(4 \mathrm{~A})$ & $-x, 2-y,-z$ & 0.85 & $2.802(3)$ & 1.95 & 178.4 \\
\hline $\mathrm{O}(1 \mathrm{GA})-\mathrm{H}(1 \mathrm{GA}) \cdots \mathrm{O}(4 \mathrm{~A})$ & $-x, 2-y,-z$ & 0.84 & $2.606(3)$ & 1.77 & 172.6 \\
\hline $\mathrm{O}(4)-\mathrm{H}(4) \cdots \mathrm{O}(4 \mathrm{~A})$ & $x, y, z$ & 0.84 & $2.536(3)$ & 1.72 & 164.4 \\
\hline $\mathrm{C}(1)-\mathrm{H}(1 \mathrm{C}) \cdots \mathrm{F}(1 \mathrm{~A})$ & $1-x, 1-y,-z$ & 0.98 & $2.949(4)$ & 2.63 & 99.4 \\
\hline $\mathrm{C}(1 \mathrm{G})-\mathrm{H}(1 \mathrm{G} 2) \cdots \mathrm{F}(1)$ & $0.5-x, 0.5+y, 0.5-z$ & 0.99 & $3.204(4)$ & 2.57 & 121.6 \\
\hline $\mathrm{C}(9)-\mathrm{H}(9) \cdots \mathrm{F}(2)$ & $-0.5-x, 0.5+y, 0.5-z$ & 0.95 & $3.405(4)$ & 2.64 & 138.3 \\
\hline $\mathrm{C}(1)-\mathrm{H}(1 \mathrm{~A}) \cdots \mathrm{F}(3)$ & $0.5-x,-0.5+y, 0.5-z$ & 0.98 & $3.389(4)$ & 2.62 & 135.2 \\
\hline \multicolumn{6}{|l|}{ (3) } \\
\hline $\mathrm{N}(2)-\mathrm{H}(2) \cdots \mathrm{O}(1)$ & $x, y, z$ & 0.90 & $2.595(4)$ & 1.92 & 130.3 \\
\hline $\mathrm{N}(2)-\mathrm{H}(2) \cdots \mathrm{O}(3)$ & $x, y, z$ & 0.90 & $2.612(4)$ & 1.93 & 130.9 \\
\hline $\mathrm{C}(9 \mathrm{~A})-\mathrm{H}(9 \mathrm{~A}) \cdots \mathrm{O}(2)$ & $0.5+x, 0.5-y, 0.5+z$ & 0.95 & $3.621(5)$ & 2.69 & 168.3 \\
\hline $\mathrm{C}(8)-\mathrm{H}(8) \cdots \mathrm{O}(4)$ & $x, y, z$ & 0.95 & $2.701(4)$ & 2.36 & 100.8 \\
\hline $\mathrm{N}(2 \mathrm{~A})-\mathrm{H}(2 \mathrm{~A}) \cdots \mathrm{O}(1 \mathrm{~A})$ & $x, y, z$ & 0.90 & $2.576(4)$ & 1.89 & 131.2 \\
\hline $\mathrm{N}(2 \mathrm{~A})-\mathrm{H}(2 \mathrm{~A}) \cdots \mathrm{O}(3 \mathrm{~A})$ & $x, y, z$ & 0.90 & $2.635(4)$ & 1.96 & 130.7 \\
\hline $\mathrm{O}(1 \mathrm{G})-\mathrm{H}(1 \mathrm{G}) \cdots \mathrm{O}(4 \mathrm{~A})$ & $2-x,-y, 2-z$ & 0.85 & $2.744(4)$ & 1.90 & 177.6 \\
\hline $\mathrm{O}(4)-\mathrm{H}(4) \cdots \mathrm{O}(4 \mathrm{~A})$ & $x, y, z$ & 0.84 & $2.544(4)$ & 1.73 & 163.9 \\
\hline $\mathrm{C}(1)-\mathrm{H}(1 \mathrm{~B}) \cdots \mathrm{F}(1 \mathrm{~A})$ & $1-x, 1-y, 2-z$ & 0.98 & $3.219(5)$ & 2.61 & 120.6 \\
\hline $\mathrm{C}(10)-\mathrm{H}(10) \cdots \mathrm{F}(2 \mathrm{~A})$ & $0.5+x, 0.5-y,-0.5+z$ & 0.95 & $3.165(5)$ & 2.61 & 118.0 \\
\hline $\mathrm{C}(9)-\mathrm{H}(10) \cdots \mathrm{F}(2 \mathrm{~A})$ & $2-x,-y, 2-z$ & 0.95 & $3.191(5)$ & 2.55 & 125.2 \\
\hline
\end{tabular}




\section{Captions to Scheme and Figures}

Scheme 1. Compounds discussed.

Figure 1. Perspective view of the molecular structure of $\mathbf{1}(\mathrm{LH})$ including the atom numbering scheme of the non-hydrogen atoms. Thermal ellipsoids are drawn at 50\% probability level. Broken lines represent hydrogen bonds.

Figure 2. Excerpt of the packing structure of $1(\mathrm{LH})$ showing the mode of intermolecular interactions. Heteroatoms are distinguished by different shading. Broken lines represent hydrogen bond type interactions.

Figure 3. Perspective view of the equatorial coordination plane (open lines) around a sodium ion in the complexes $\mathbf{2}$ and $\mathbf{3}$. Broken lines represent hydrogen bonds.

Figure 4. Perspective view of the complexes (a) 2 and (b) 3. Heteroatoms are distinguished by different shading. Thin lines around the sodium ions represent coordinative bonds; broken lines mean hydrogen bonds. Only one of the disordered positions of the ethanol molecule in (a) is displayed for clarity.

Figure 5. Packing motif of the complex 2. Heteroatoms are distinguished by different shading; non-relevant hydrogen atoms are omitted. Thin lines around the sodium ions represent coordinative bonds; broken lines mean hydrogen bonds. Only one of the disordered positions of the ethanol molecule is displayed for clarity. 
<smiles>CC(=O)C(=NNc1ccccc1C(=O)O)C(=O)C(F)(F)F</smiles>

$1 \quad(\mathrm{LH})$

$2\left[\mathrm{Na}_{2} \mathrm{~L}_{2}(\mathrm{LH})_{2}\right] \cdot 2 \mathrm{EtOH}$

$3 \quad\left[\mathrm{Na}_{2} \mathrm{~L}_{2}(\mathrm{LH})_{2}\right] \cdot 2 n-\mathrm{BuOH}$

Scheme 1 


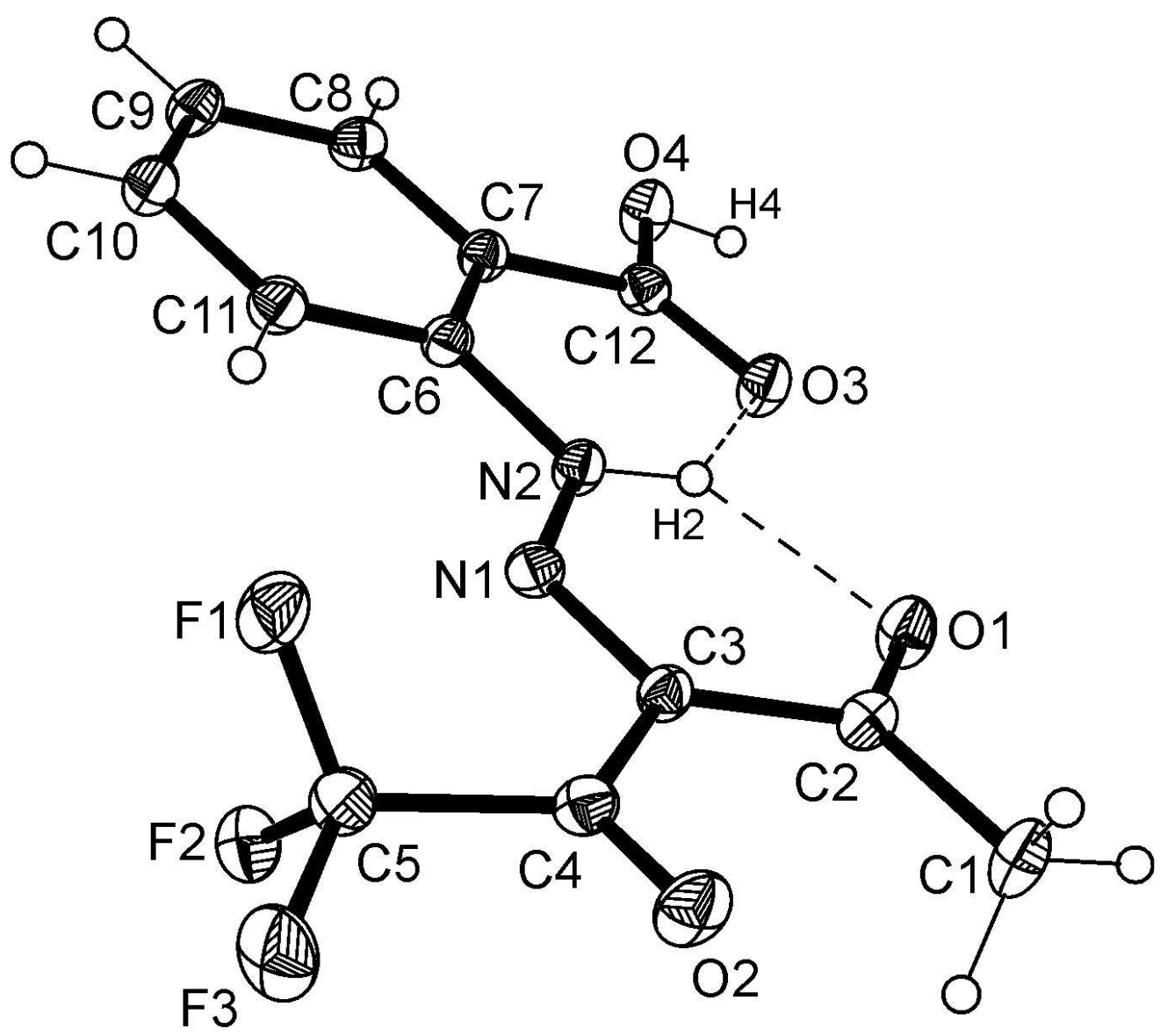

Fig. 1 


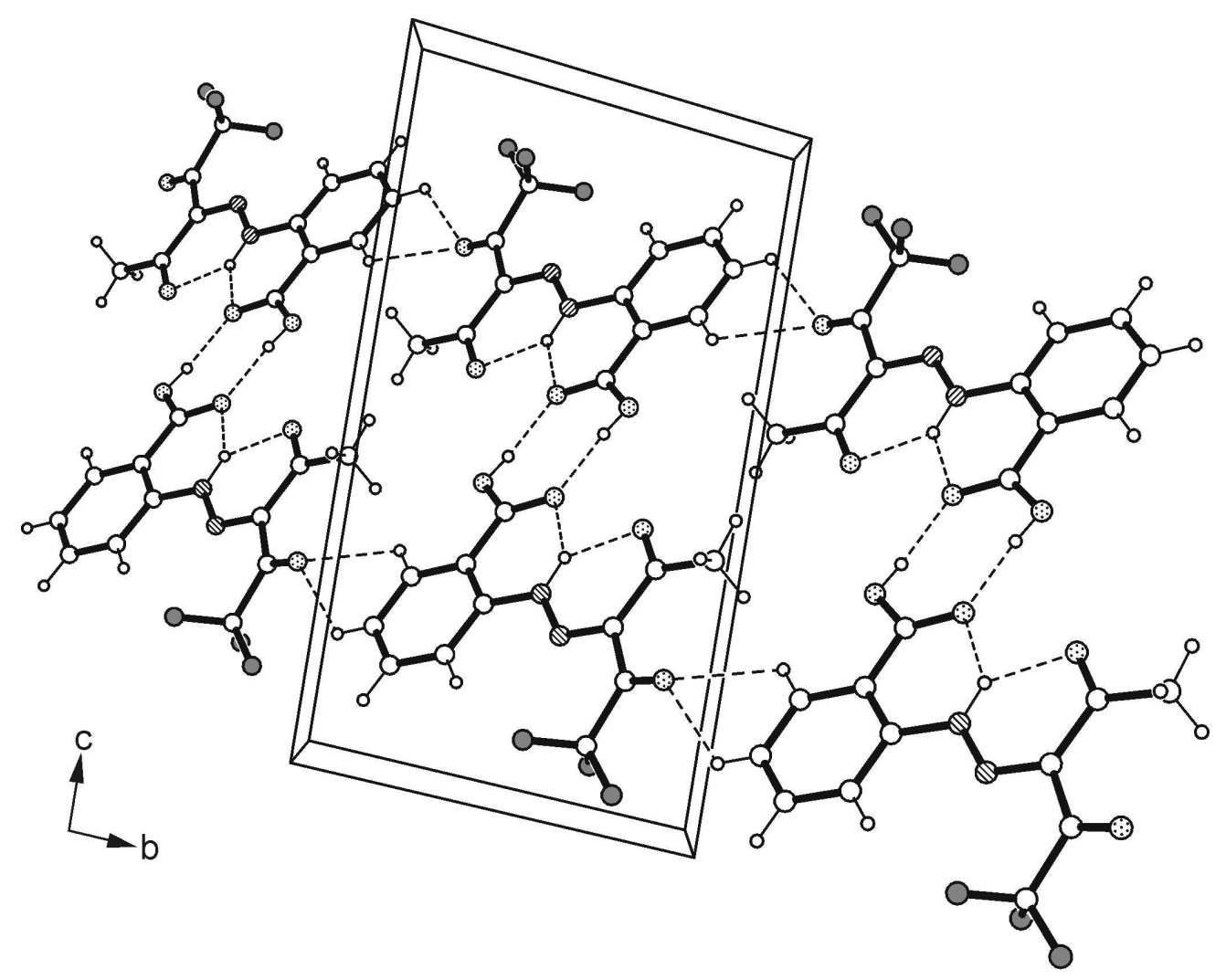

Fig. 2 


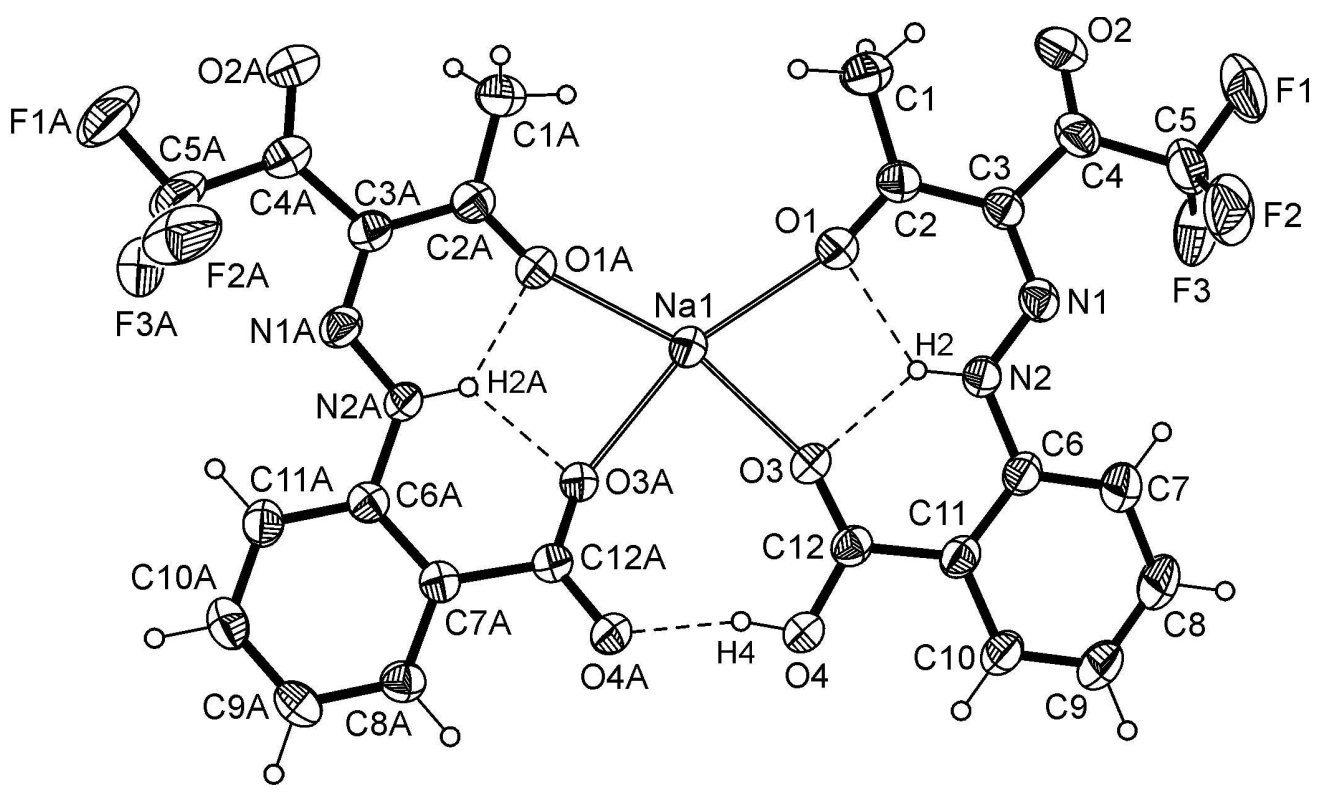

Fig. 3 
(a)

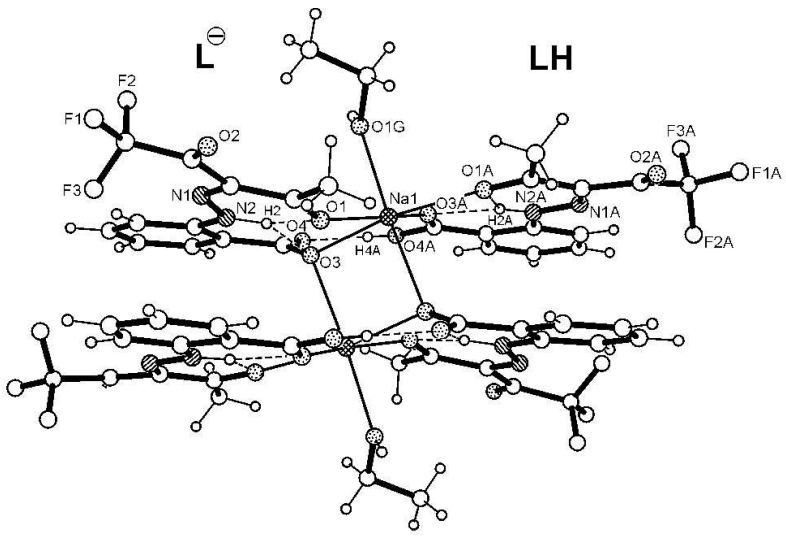

(b)

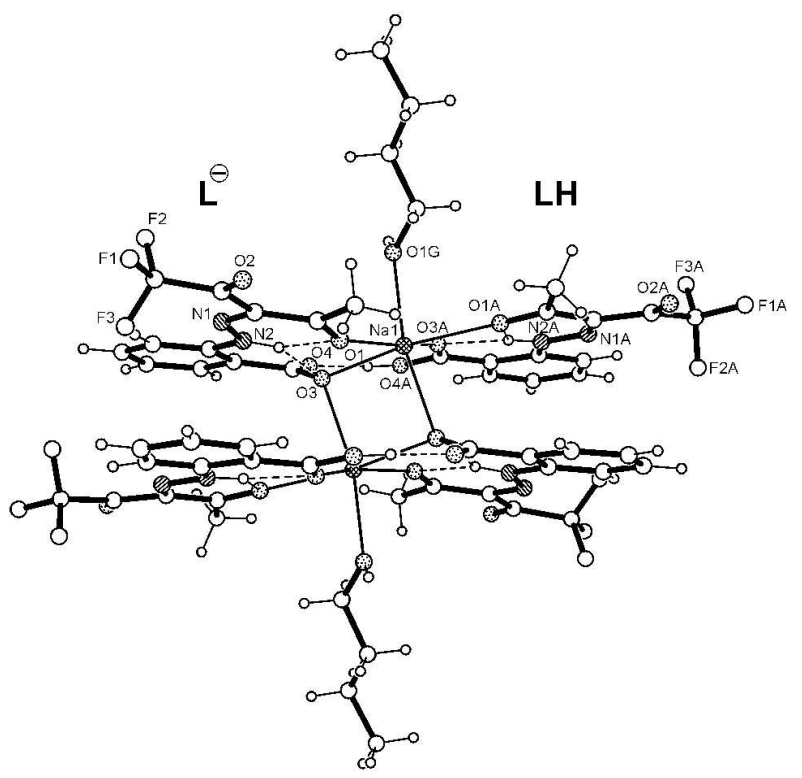

Fig. 4 


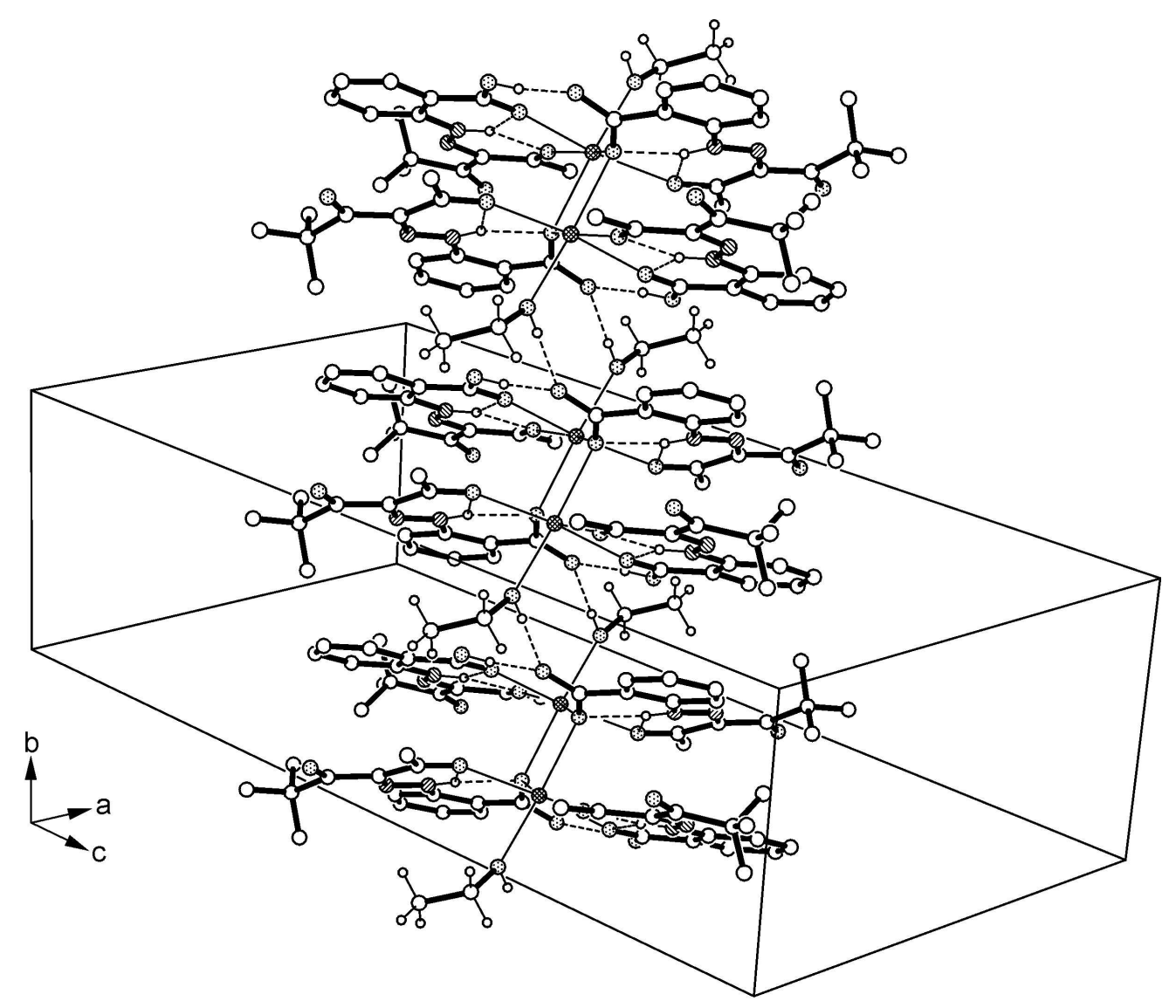

Fig. 5 